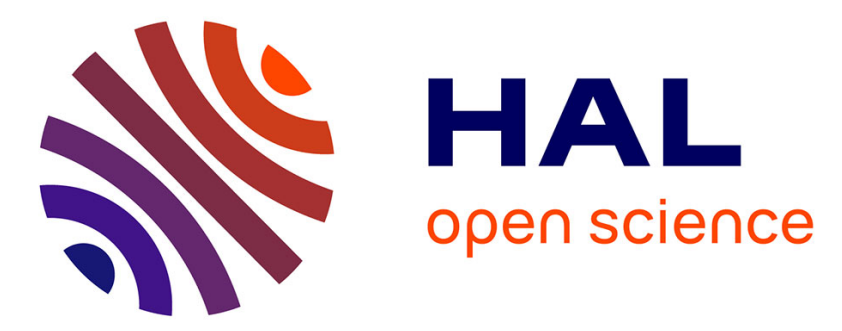

\title{
Electrochemical Investigation of the Corrosion Behavior of API 5L-X65 Carbon Steel in Carbon Dioxide Medium
}

\author{
Magaly Henriquez Gonzalez, Nadine Pébère, Nathalie Ochoa, A. Viloria
}

\section{To cite this version:}

Magaly Henriquez Gonzalez, Nadine Pébère, Nathalie Ochoa, A. Viloria. Electrochemical Investigation of the Corrosion Behavior of API 5L-X65 Carbon Steel in Carbon Dioxide Medium. Corrosion, 2013, vol. 69 ( $\left.\mathrm{n}^{\circ} 12\right)$, pp. 1171-1179. 10.5006/0971 . hal-01166085

\section{HAL Id: hal-01166085 \\ https://hal.science/hal-01166085}

Submitted on 22 Jun 2015

HAL is a multi-disciplinary open access archive for the deposit and dissemination of scientific research documents, whether they are published or not. The documents may come from teaching and research institutions in France or abroad, or from public or private research centers.
L'archive ouverte pluridisciplinaire HAL, est destinée au dépôt et à la diffusion de documents scientifiques de niveau recherche, publiés ou non, émanant des établissements d'enseignement et de recherche français ou étrangers, des laboratoires publics ou privés. 


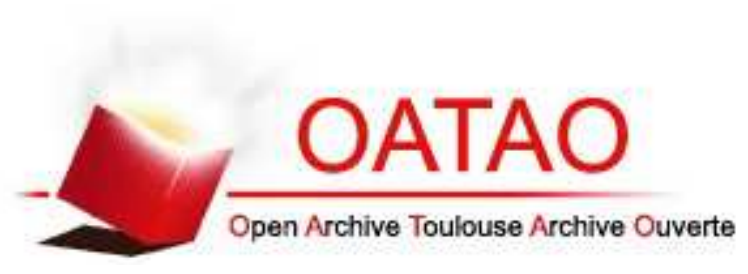

\section{Open Archive TOULOUSE Archive Ouverte (OATAO)}

OATAO is an open access repository that collects the work of Toulouse researchers and makes it freely available over the web where possible.

This is an author-deposited version published in : http://oatao.univ-toulouse.fr/ Eprints ID : 14077

To link to this article : doi: $10.5006 / 0971$

URL : http://dx.doi.org/10.5006/0971

To cite this version : Henriquez Gonzalez, Magaly and Pébère, Nadine and Ochoa, Nathalie and Viloria, A. Electrochemical Investigation of the Corrosion Behavior of API 5L-X65 Carbon Steel in Carbon Dioxide Medium. (2013) Corrosion, vol. 69 (n 12). pp. 1171-1179. ISSN 0010-9312

Any correspondance concerning this service should be sent to the repository administrator: staff-oatao@listes-diff.inp-toulouse.fr 


\section{Electrochemical Investigation of the Corrosion Behavior of API 5L-X65 Carbon Steel in Carbon Dioxide Medium}

M. Henriquez, ${ }^{\star}$ N. Pébère, ${ }^{*}$ N. Ochoa, ${ }^{\ddagger, \star *}$ and A. Viloria ${ }^{* * *}$

\section{ABSTRACT}

The corrosion behavior of API 5L-X65 carbon steel in a carbon dioxide $\left(\mathrm{CO}_{2}\right)$-saturated solution was investigated by electrochemical measurements (polarization curves, Levich plots, and electrochemical impedance spectroscopy) with a rotating disk electrode. Different experimental conditions such as hydrodynamics, immersion time, and temperature were considered. From the polarization curves, it was shown that both the anodic and cathodic current densities decreased as the electrode rotation speed, the immersion time, and the temperature increased. This behavior was in agreement with the impedance results obtained at the corrosion potential. It was shown that the corrosion processes were initially controlled by mass transport but they became under activation control for longer immersion times. Scanning electron microscopy was used to characterize the corrosion products. For short immersion times ( $2 \mathrm{~h}$ and $6 \mathrm{~h}$ ), the corrosion products mainly deposited on the cathodic sites (pearlitic zones) of the carbon steel surface forming a heterogeneous layer, whereas they covered the whole electrode surface after longer periods (>15 h). At a microscale, localized corrosion, as a result of galvanic coupling between pearlite and ferrite, was also observed.

KEY WORDS: carbon steel, $\mathrm{CO}_{2}$ corrosion, corrosion products, impedance

Submitted for publication: March 13, 2013. Revised and accepted: June 6, 2013. Preprint available online: July 1, 2013, doi: http:// dx.doi.org/10.5006/0971.

${ }^{\ddagger}$ Corresponding author. E-mail: nochoa@usb.ve.

* Université de Toulouse, CIRIMAT, UPS/INPT/CNRS, ENSIACET, 4, allée Emile Monso BP 44362, 31030 Toulouse Cedex 4, France.

** Departamento de Ciencia de los Materiales, Universidad Simón Bolívar, Caracas 1080-A, Venezuela.

*** Escuela de Ingeniería Química, Universidad Central de Venezuela Caracas 1080-A, Venezuela.

\section{INTRODUCTION}

Dissolved in aqueous solutions, carbon dioxide $\left(\mathrm{CO}_{2}\right)$ causes severe corrosion problems on steel pipelines and process equipments used in extraction, production, and transport of oil and natural gas. The mechanisms of corrosion in $\mathrm{CO}_{2}$ environments have been studied for more than 30 years, but the damage caused by this type of degradation is still difficult to predict because of the complexity of the phenomena. A large number of variables such as $\mathrm{pH}$, temperature, pressure, flow, brine composition, steel composition, and the presence of surface films have a direct influence on the corrosion of carbon steels in $\mathrm{CO}_{2}-$ containing media. Moreover, these parameters affect the efficiency of inhibitive formulations that are used to limit corrosion.

The corrosion of steel in aqueous solutions of $\mathrm{CO}_{2}$ is strongly influenced by the formation of surface films, which decreases the corrosion rate. ${ }^{1-2}$ These films are generally composed of a mixture of iron carbonate or siderite $\left(\mathrm{FeCO}_{3}\right)$ and non-dissolved cementite. ${ }^{3-5}$ The formation of iron carbonate is dependent on $\mathrm{Fe}^{2+}$, bicarbonate and carbonate ion concentration, $\mathrm{pH}$, and temperature. As the temperature increases, the solubility product of iron carbonates (Ksp) decreases and adhesion to the metal surface is improved. . $^{6-7}$

In the present work, different parameters such as immersion time, flow, and temperature that control the corrosion kinetic of API 5L-X65 carbon steel in $\mathrm{CO}_{2}$-containing media were investigated. Current-voltage curves and electrochemical impedance diagrams 


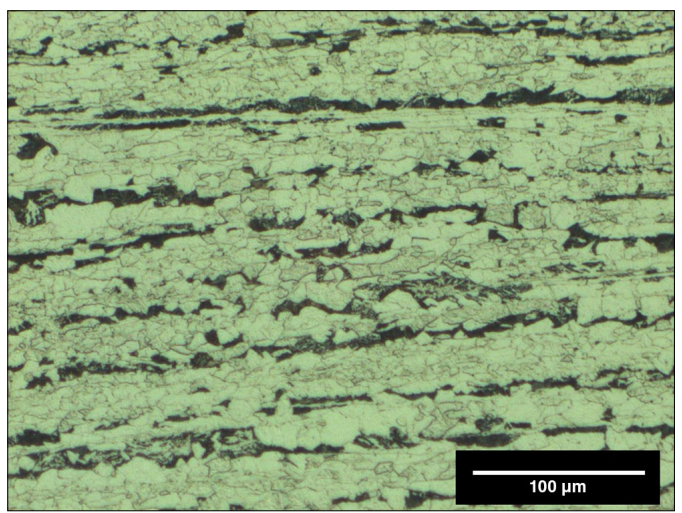

FIGURE 1. Optical micrograph of API 5L-X65 carbon steel.

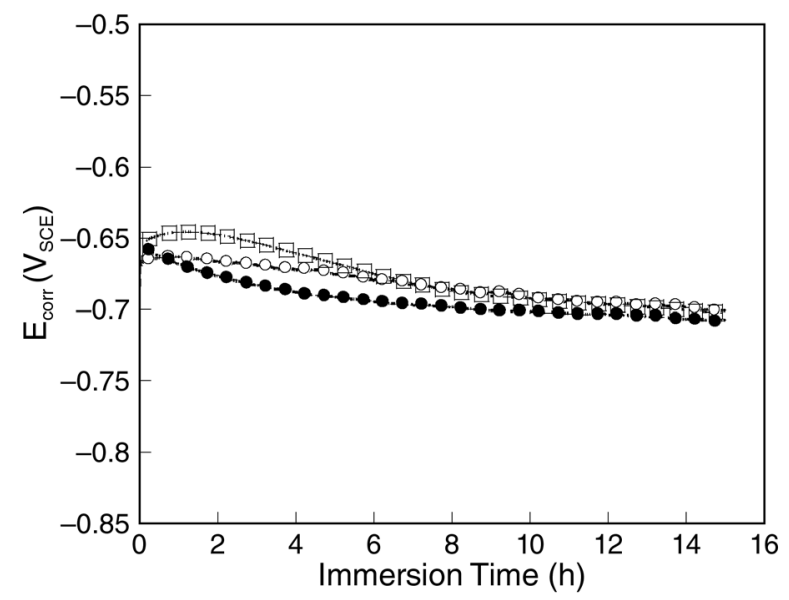

FIGURE 2. Corrosion potential vs. immersion time in a $0.5 \mathrm{M} \mathrm{NaCl}$ solution saturated with $\mathrm{CO}_{2}:$ (O) $400 \mathrm{rpm}$, ( $\square$ ) 1,000 rpm, and (•) $1,600 \mathrm{rpm}$.

were obtained in a deaerated sodium chloride solution $(0.5 \mathrm{M} \mathrm{NaCl})$ saturated with $\mathrm{CO}_{2}$ using a rotating disk electrode. From the electrochemical results, the corrosion rate of the carbon steel was calculated. The electrochemical data were complemented by scanning electron microscopy (SEM) observations of the electrode surface after immersion.

\section{EXPERIMENTAL PROCEDURES}

\section{Material}

The API 5L-X65 carbon steel samples were taken directly from a pipeline (longitudinal section). Its composition in percent weight was C 0.28 , Mn 1.45 , $\mathrm{P} 0.03$, Ti 0.06, and Fe to 100 . The microstructure of the carbon steel is shown in Figure 1. It is characteristic of ferritic-pearlitic steels and it consists of an $\alpha$-phase (ferrite) and eutectoid mixture (pearlite) composed of intercalated lamellae of $\alpha$ phase and cementite $\left(\mathrm{Fe}_{3} \mathrm{C}\right)$. These microcomponents, observed as the white and gray colors on the optical photomicrograph,

\footnotetext{
${ }^{+}$Trade name.
}

are distributed forming bands, which are characteristic of the manufacturing process of steel pipes. The percentage of the two phases was quantified using Aphelion ${ }^{\dagger}$ software, which resulted in $22 \%$ pearlite and $78 \%$ ferrite.

\section{Electrochemical Measurements}

A borosilicate glass, double-wall vessel of $250 \mathrm{~mL}$ was used as the electrochemical cell. It contained a platinum grid auxiliary electrode, a saturated calomel reference electrode (SCE), and a rod of API 5L-X65 carbon steel, of $1 \mathrm{~cm}^{2}$ cross-sectional area, used as the working electrode. The body of the rod was covered with a heat-shrinkable sheath, leaving only the tip of the carbon steel cylinder in contact with the solution. Before the experiments, the surface was grinded with silicon carbide $(\mathrm{SiC})$ paper down to grade 1200.

The corrosive medium was a $0.5 \mathrm{M}$ solution of $\mathrm{NaCl}$ (reagent grade), initially purged with nitrogen for $30 \mathrm{~min}$, and then $\mathrm{CO}_{2}$ was bubbled for $1 \mathrm{~h}$ before the introduction of the samples into the cell. $\mathrm{CO}_{2}$ bubbling was maintained during the experiment. The $\mathrm{pH}$ of the $\mathrm{CO}_{2}$-saturated solutions was monitored during the electrochemical measurements. The $\mathrm{pH}$ value remained between 3.7 and 4 from the beginning to the end of the experiments. When the temperature of the brine was increased to $60^{\circ} \mathrm{C}$, the $\mathrm{pH}$ of the bulk solution slightly increased to 4.5 to 5 , and it also remained stable during the corrosion test.

Polarization curves were obtained under potentiodynamic regulation using a Solartron $1287^{\dagger}$ electrochemical interface. The cathodic and anodic branches were traced consecutively with a scan rate of $0.6 \mathrm{~V} / \mathrm{h}$. Electrochemical impedance measurements were carried out at the corrosion potential using the electrochemical interface connected to a Solartron $1250^{\dagger}$ frequency response analyzer. Impedance diagrams were obtained over a frequency range of $65 \mathrm{kHz}$ to a few $\mathrm{mHz}$ with 8 points per decade using a $15 \mathrm{mV}$ peak-to-peak sinusoidal voltage. The electrochemical results were obtained from at least three experiments to ensure reproducibility.

\section{Surface Analysis}

SEM analyses were carried out on a LEO $435 \mathrm{VP}^{\dagger}$ instrument. Observations were performed after sample immersion in the aggressive solution after different immersion times and temperatures.

\section{RESULTS AND DISCUSSION}

\section{Influence of Flow and Immersion Time $\left(T=25^{\circ} \mathrm{C}\right)$}

Stationary Measurements - Figure 2 illustrates

the variation of corrosion potential $\left(\mathrm{E}_{\text {corr }}\right)$ of the carbon steel electrode in the aggressive solution as a function of the immersion time and for three electrode rotation speeds. It can be seen that $\mathrm{E}_{\text {corr }}$ is fairly similar for the three rotation speeds. The $\mathrm{E}_{\text {corr }}$ evolves slightly toward 
more a cathodic potential as the immersion time increases, and, after $10 \mathrm{~h}$ of immersion, it can be seen to stabilize around $-0.7 \mathrm{~V}_{\mathrm{SCE}}$. The variation of $\mathrm{E}_{\mathrm{corr}}$ during the immersion remained low (about $50 \mathrm{mV}$ ).

The polarization curves obtained at $25^{\circ} \mathrm{C}$ for different experimental conditions are reported in Figure 3. They were obtained for three electrode rotation speeds, $400 \mathrm{rpm}, 1,000 \mathrm{rpm}$, and 1,600 rpm, and the curves were plotted after a preliminary hold time at $\mathrm{E}_{\text {corr }}$ of $2 \mathrm{~h}, 6 \mathrm{~h}$, and $15 \mathrm{~h}$, for each rotation speed. In agreement with the chronopotentiometry results, $\mathrm{E}_{\text {corr }}$ shifted toward negative values as the immersion time increased. In the anodic domain, two types of curves were observed depending on the rotation speed or the immersion time. The first type of curve, obtained for the three electrode rotation speeds and after $2 \mathrm{~h}$ of immersion, was characterized by a sharp increase of the current density near the corrosion potential. For the second type of curve, which also concerned the three rotation speeds but longer immersion times, the current densities were lower by comparison with those obtained for shorter immersion times. Independently of the experimental conditions, a pseudo-passivation phenomenon was observed in the potential domain from about $-0.5 \mathrm{~V}_{\mathrm{SCE}}$, where a current plateau was always observed. This plateau, also obtained by Zhang and Cheng, ${ }^{8}$ indicates the accumulation of corrosion products that partially block the steel surface when the immersion time increases. Indeed, Linter and Burstein ${ }^{9}$ attributed the presence of the current plateau to the formation of a poorly protective anodic film composed of iron carbonate: the current densities were too high (around $10 \mathrm{~mA} \mathrm{~cm}^{-2}$ ) to be regarded as arising from the passive state. In the cathodic domain, for the three rotation speeds, the current densities strongly decreased as the immersion time increased. This effect was more marked after $15 \mathrm{~h}$ of immersion. After $2 \mathrm{~h}$ of immersion, a well-defined current plateau was reached, which is ascribed to the mass-transport limitation of the proton reduction reaction. ${ }^{9-10}$ Between $6 \mathrm{~h}$ and $15 \mathrm{~h}$, the diffusion plateau disappeared indicating that cathodic kinetics became under activation control; after $15 \mathrm{~h}$ of immersion, a Tafelian behavior was observed.

To understanding of the influence of flow on the electrode kinetics, I was plotted against $\Omega^{1 / 2}$ over the cathodic domain at a potential of $-0.87 \mathrm{~V}_{\mathrm{SCE}}$ (Figure 4). The curves were plotted after different preliminary hold times at the corrosion potential and for an initial electrode rotation speed of $400 \mathrm{rpm}$. Then, the cathodic potential was applied and the rotation speed increased. For each rotation speed, the current density was measured after 5 min of stabilization. Independently of the immersion time, the current densities increased with the square root of the electrode rotation speed. This can be explained by an increase of the $\mathrm{H}^{+}$supply at the metal surface. ${ }^{9-10}$ However, the curves do not cross the origin. This has been ex-
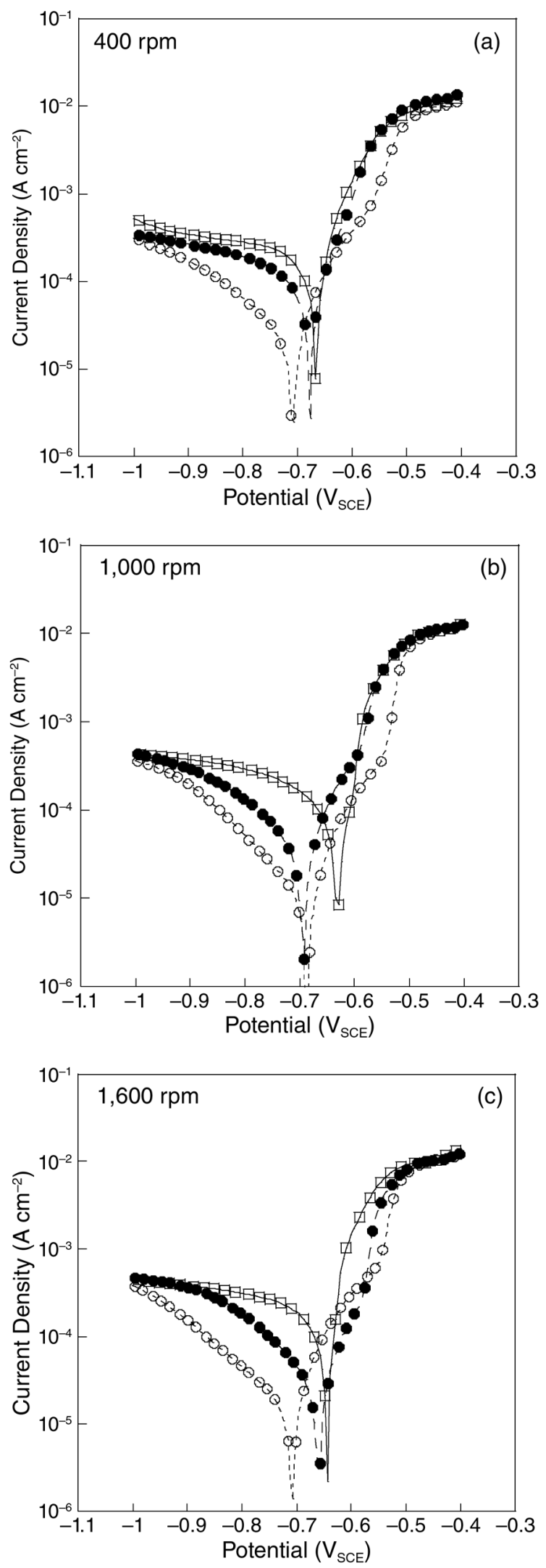

FIGURE 3. Current-voltage curves plotted after different immersion times at the corrosion potential in a $0.5 \mathrm{M} \mathrm{NaCl}$ solution saturated with $\mathrm{CO}_{2}:(\square) 2 h$, (○) $6 h$, (O) $15 h$; for three electrode rotation speeds: (a) $400 \mathrm{rpm}$, (b) 1,000 rpm and (c) 1,600 rpm. 


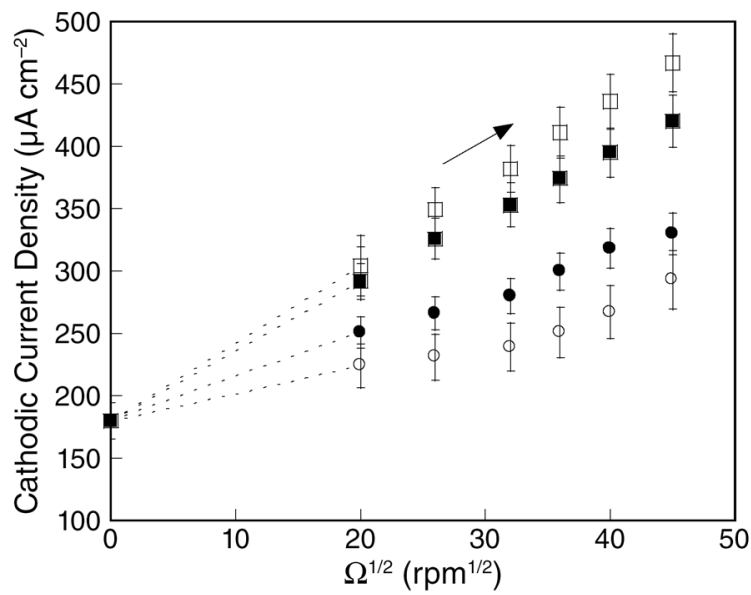

FIGURE 4. Levich curves plotted at $E=-0.87 V_{S C E}$ and after different immersion times in a $0.5 \mathrm{M} \mathrm{NaCl}$ solution saturated with $\mathrm{CO}_{2}:(\square) 2 \mathrm{~h},(\boldsymbol{\square}) 4 \mathrm{~h},(\mathbf{0}) 6 \mathrm{~h}$, and (O) $15 \mathrm{~h}$.

plained by the buffering effect induced by the presence of the dissolved $\mathrm{CO}_{2}$ in the solution, which leads to an additional contribution in the cathodic currents. ${ }^{10}$ Moreover, the extrapolated current density at $\Omega=0 \mathrm{rpm}$ was independent of the immersion time at $\mathrm{E}_{\text {corr }}$ (around $175 \mu \mathrm{A} \cdot \mathrm{cm}^{-2}$ ). This result is in agreement with that obtained by Remita, et al., ${ }^{10}$ and corroborated the fact that this current was originated by the acidic dissociation of dissolved $\mathrm{CO}_{2}$.

It can also be observed that the cathodic current densities sharply decreased as the immersion time increased in agreement with results obtained from the polarization curves. It can be seen that the Levich slope decreased by a factor of 2.5 to 3 between $2 \mathrm{~h}$ and $15 \mathrm{~h}$ of immersion. These results indicate a decrease of the active surface area available for the hydrogen reduction because of the deposition of the insulating corrosion products on the carbon steel surface..$^{2-7}$ Besides, for $2 \mathrm{~h}$ and $4 \mathrm{~h}$ of immersion, straight lines were obtained, but for longer immersion times ( $6 \mathrm{~h}$ and $15 \mathrm{~h}$ ), lines with different slopes can be seen. Above $1,000 \mathrm{rpm}$, the increase of the current densities became higher as the electrode rotation speed increased. Mechanical removal of poorly adherent corrosion products caused by a flow increase over the electrode surface can explain this behavior. ${ }^{11}$

Electrochemical Impedance Measurements - First, the impedance diagrams were obtained at $\mathrm{E}_{\text {corr }}$ at $25^{\circ} \mathrm{C}$ (Figure 5). Each diagram was obtained separately for three electrode rotation speeds $(400 \mathrm{rpm}, 1,000 \mathrm{rpm}$, and 1,600 rpm) after three immersion times $(2 \mathrm{~h}, 6 \mathrm{~h}$, and $15 \mathrm{~h}$ ). The spectra showed the same shape. They consisted of a capacitive loop at medium frequencies and an inductive loop at low frequencies. This behavior is commonly observed in the presence of $\mathrm{CO}_{2} \cdot{ }^{8,12-13}$ The capacitive loop, observed at medium frequencies, is usually attributed to charge-transfer resistance on bare metal surface (uncovered zones by the corrosion
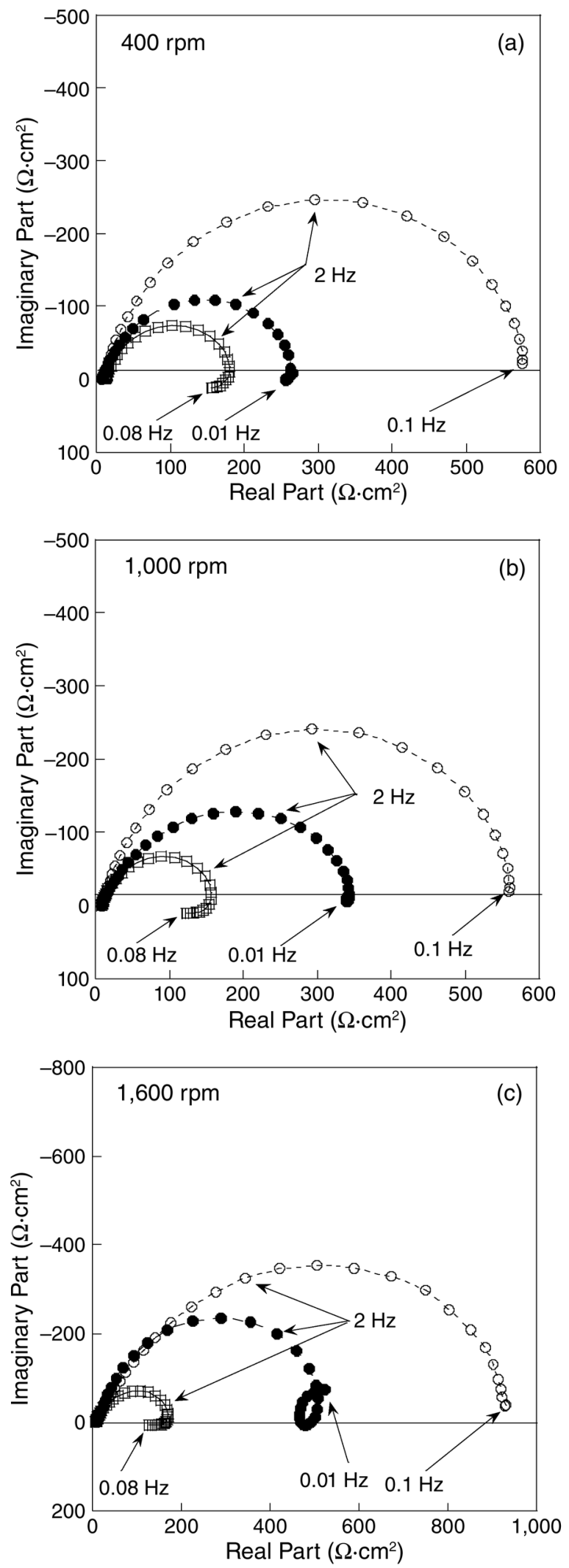

FIGURE 5. Electrochemical impedance diagrams plotted independently at the corrosion potential after different immersion times in a $0.5 \mathrm{M} \mathrm{NaCl}$ solution saturated with $\mathrm{CO}_{2}:(\square) 2 \mathrm{~h}$, (•) $6 \mathrm{~h}$, and (O) $15 \mathrm{~h}$; for three electrode rotation speeds: (a) $400 \mathrm{rpm}$, (b) $1,000 \mathrm{rpm}$, and (c) 1,600 rpm. 
products). Inductive loops are generally ascribed to the existence of relaxation processes of adsorbed species at the metal/solution interface such as $\mathrm{H}^{+}, \mathrm{HCO}_{3}^{-}$, and/or carbonic acid $\left(\mathrm{H}_{2} \mathrm{CO}_{3}\right) .{ }^{12-15}$

It can be seen that the amplitude of the diagrams was affected by the studied parameters. More particularly, the size of the capacitive loop was higher when the immersion time increased, which is most visible at 1,600 rpm. These results are consistent with the current-voltage curves and the Levich plots, indicating a decrease of the active surface area by the corrosion products. In addition, when the immersion time increases, the inductive part tends to disappear and the diagrams are composed of only one capacitive loop. This behavior can be attributed to a large amount of corrosion products covering the electrode surface, in agreement with Zhang and Cheng ${ }^{8}$ and Farelas, et al. ${ }^{13}$ For the highest rotation speed and when the protection afforded by the corrosion products is higher, the inductive loop tends to close on itself, giving rise to another capacitive loop, which is characteristic of an active-passive transition. ${ }^{16}$

To assess contribution of mass transport on the impedance response, the impedance diagrams were also obtained consecutively, using the same protocol as for the Levich curves. The electrode was first maintained at $\mathrm{E}_{\text {corr }}$ for $2 \mathrm{~h}$ or for $15 \mathrm{~h}$ at a rotation speed of $400 \mathrm{rpm}$, then, the electrode rotation speed was increased at 1,000 rpm and 1,600 rpm, and the diagrams were plotted for each rotation speed (Figure 6). In this case, it can be seen that the size of the diagrams decreased when the rotation speed increased; nevertheless, after $15 \mathrm{~h}$ of immersion, the spectra were poorly modified by the hydrodynamics. For longer immersion times, the diagrams were always constituted by a single capacitive loop, whereas inductive part was systematically obtained after $2 \mathrm{~h}$ of immersion. The impedance results, in agreement with the modification of the cathodic curves with the exposure time and the Levich plots, indicate that the corrosion process is initially influenced by mass transport, but it became mainly controlled by charge transfer when the immersion time increased.

Equivalent electrical circuits are frequently used to extract the parameters associated with the impedance diagrams where a constant phase element (CPE) is used instead of a capacitance to take into account the non-ideal behavior of the interface. ${ }^{17}$ The CPE is given by:

$$
Z_{\mathrm{CPE}}-\frac{1}{\mathrm{Q}(j \omega)^{\alpha}}
$$

where $\alpha$ is related to the angle of rotation of a purely capacitive line on the complex plane plots and $Q$ is in $\Omega^{-1} \mathrm{~cm}^{-2} \mathrm{~s}^{\alpha}$. In the present study, the electrolyte resistance $\left(R_{e}\right)$ and the resistance associated to the capacitive loop $\left(R_{T}\right)$ were directly measured on the impedance
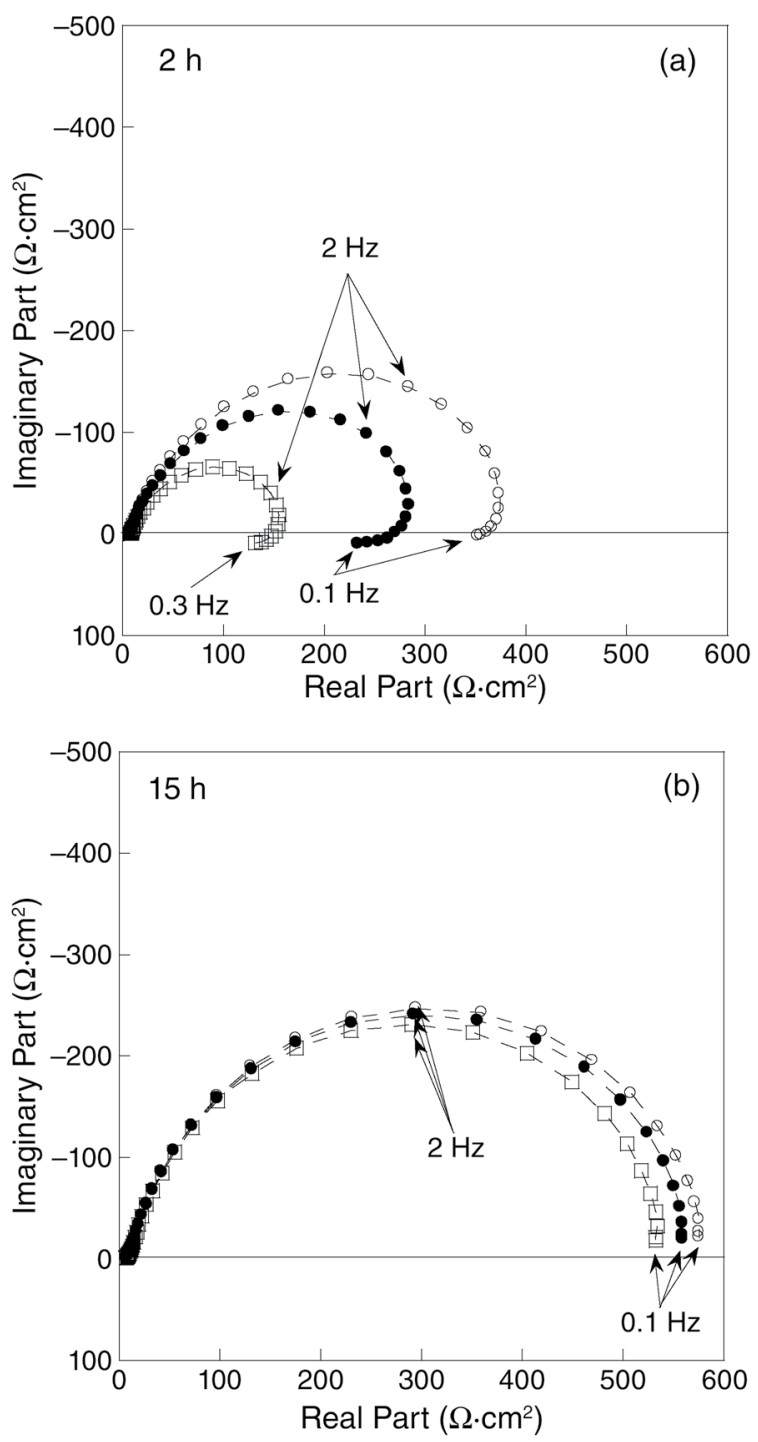

FIGURE 6. Electrochemical impedance diagrams plotted consecutively at the corrosion potential after (a) $2 h$ and (b) $15 h$ of immersion in a $0.5 \mathrm{M} \mathrm{NaCl}$ solution saturated with $\mathrm{CO}_{2}$ : (O) $400 \mathrm{rpm}$, (•) 1,000 rpm, and ( $\square$ ) 1,600 rpm.

spectra and the CPE parameters ( $\alpha$ and $\mathrm{Q}$ ) were graphically determined. ${ }^{18}$ The effective capacitance, $\mathrm{C}_{\text {eff }}$ (expressed in Farads), was calculated from the CPE parameters considering a distribution of the chargetransfer resistances on the electrode surface: ${ }^{19}$

$$
C_{\text {eff }}=Q^{1 / \alpha}\left(R_{e} R_{T} / R_{e}+R_{T}\right)^{(1-\alpha) / \alpha}
$$

In the limit that $R_{T}$ becomes much larger than $R_{e}$, Equation (2) becomes:

$$
\mathrm{C}_{\text {eff }}=\mathrm{G}^{1 / \alpha} \mathrm{R}_{\mathrm{e}}^{(1-\alpha) / \alpha}
$$

Parameters corresponding to impedance diagrams shown in Figures 5 and 6 are reported in Tables 1 and 2 , respectively. Independently of the protocol used, 
TABLE 1

Electrochemical Parameters Obtained from the Impedance Diagrams Presented in Figure 5

\begin{tabular}{|c|c|c|c|c|c|c|c|c|c|}
\hline \multirow{2}{*}{$\begin{array}{l}\text { Rotation Speed (rpm) } \\
\text { Immersion time }(\mathrm{h})\end{array}$} & \multicolumn{3}{|c|}{400} & \multicolumn{3}{|c|}{1,000} & \multicolumn{3}{|c|}{1,600} \\
\hline & 2 & 6 & 15 & 2 & 6 & 15 & 2 & 6 & 15 \\
\hline $\mathrm{R}_{\mathrm{e}}\left(\Omega \cdot \mathrm{cm}^{2}\right)$ & 7.5 & 7.2 & 7.0 & 8.1 & 7.4 & 7.2 & 7.2 & 7.4 & 7.8 \\
\hline $\mathrm{R}_{\mathrm{T}}\left(\Omega \cdot \mathrm{cm}^{2}\right)$ & 163 & 259 & 559 & 143 & 338 & 555 & 150 & 522 & 959 \\
\hline $\mathrm{Q}\left(\mathrm{M} \Omega^{-1} \mathrm{~cm}^{-2} \mathrm{~s}^{\alpha}\right)$ & 459 & 544 & 464 & 445 & 337 & 440 & 410 & 219 & 245 \\
\hline $\mathrm{C}^{1}{ }_{\mathrm{eff}}\left(\mu \mathrm{Fcm}^{-2}\right)$ & 68 & 77 & 45 & 82 & 36 & 86 & 52 & 32 & 27 \\
\hline
\end{tabular}

TABLE 2

Electrochemical Parameters Obtained from the Impedance Diagrams Presented in Figure 6

\begin{tabular}{lcccccc}
\hline Immersion Time (h) & \multicolumn{3}{c}{$\mathbf{2}$} & \multicolumn{3}{c}{$\mathbf{1 5}$} \\
\hline Rotation speed (rpm) & 400 & 1,000 & 1,600 & 400 & 1,000 & 1,600 \\
$\mathrm{R}_{\mathrm{e}}\left(\Omega \cdot \mathrm{cm}^{2}\right)$ & 7.9 & 7.9 & 8.0 & 6.8 & 6.4 & 6.8 \\
$\mathrm{R}_{\mathrm{T}}\left(\Omega \cdot \mathrm{cm}^{2}\right)$ & 374 & 282 & 155 & 576 & 559 & 532 \\
$\alpha$ & 0.78 & 0.78 & 0.76 & 0.79 & 0.79 & 0.79 \\
$\mathrm{Q}\left(\mathrm{M}^{-1} \mathrm{~cm}^{-2} \mathrm{~s}^{\alpha}\right)$ & 266 & 277 & 370 & 301 & 303 & 306 \\
$\mathrm{C}^{1}{ }_{\mathrm{eff}}\left(\mu \mathrm{Fcm}^{-2}\right)$ & 46 & 49 & 58 & 58 & 58 & 59 \\
\hline
\end{tabular}

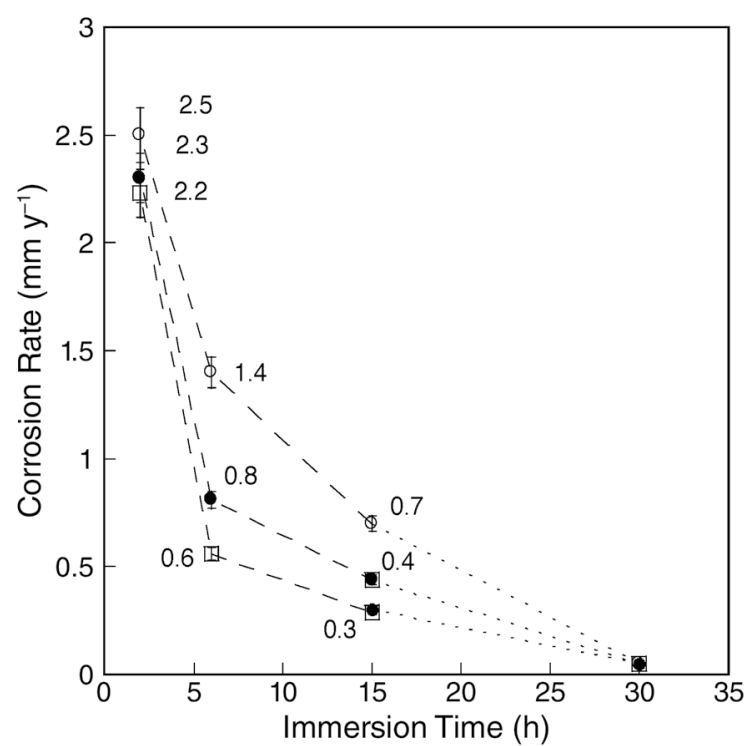

FIGURE 7. Corrosion rates of the carbon steel API $5 L-X 65$ calculated at $25^{\circ} \mathrm{C}$ for the three rotation speeds and different times of immersion in a $0.5 \mathrm{M} \mathrm{NaCl}$ solution saturated with $\mathrm{CO}_{2}:(\mathrm{O})$ $400 \mathrm{rpm}$, (0) 1,000 rpm, and ( $\square$ ) 1,600 rpm.

the $R_{T}$ values increased with immersion time, the $\alpha$ values appeared to be between 0.71 and 0.79 , and the capacitance values were lower than $100 \mu \mathrm{F} \mathrm{cm}{ }^{-2}$. It can be noted that the product $\mathrm{R}_{\mathrm{T}} \cdot \mathrm{C}_{\text {eff }}$ was not constant. Therefore, it can be assumed that $\mathrm{C}_{\text {eff }}$ take into account both the double-layer capacitance on the active area and the capacitance of the corrosion products.

Corrosion Rates - Results obtained from electrochemical measurements were summarized calculating corrosion rates $\left(\mathrm{C}_{\mathrm{R}}\right)$ of the carbon steel for the different conditions studied (Figure 7). The corrosion rates were calculated according to the ASTM G102-4 standard $^{20}$ from the equation:

$$
\mathrm{C}_{\mathrm{R}}=\frac{\mathrm{K} \cdot \mathbf{i}_{\text {corr }} \cdot \mathrm{EW}}{\rho}
$$

$\mathrm{K}$ is a constant $\left(3.27 \times 10^{-3} \mathrm{~mm} \cdot \mathrm{g} / \mu \mathrm{A} \cdot \mathrm{cm} \cdot \mathrm{y}\right), \rho$ is the metal density $\left(7.86 \mathrm{~g} / \mathrm{cm}^{3}\right)$, and $\mathrm{EW}$ is the equivalent weight of the carbon steel. ${ }^{28}$ The values of the corrosion current density $\left(i_{\text {corr }}\right)$ were calculated from the Stern and Geary Equation: ${ }^{21}$

$$
\mathrm{i}_{\text {corr }}=\frac{\beta_{\mathrm{a}} \beta_{\mathrm{c}}}{2.3 \mathrm{R}_{\mathrm{T}}\left(\beta_{\mathrm{a}}+\beta_{\mathrm{c}}\right)}
$$

$R_{T}$ values were obtained from the impedance diagrams, and the anodic $\left(\beta_{\mathrm{a}}\right)$ and cathodic $\left(\beta_{\mathrm{c}}\right)$ Tafel slopes were measured from the polarization curves. Because of the difficulty to obtain Tafel slopes accurately for some curves (lack of linearity of the polarization curves in the vicinity of the corrosion potential), average values were used: $70 \mathrm{mV}$ decade $^{-1}$ for $\beta_{\mathrm{a}}$ and $190 \mathrm{mV}$ decade $^{-1}$ for $\beta_{\mathrm{c}}$. In the literature, the values reported for $\beta_{\mathrm{a}}$ and $\beta_{\mathrm{c}}$ are of the same order of magnitude. For example, Farelas, et al., ${ }^{13}$ reported $40 \mathrm{mV}$ decade $^{-1}$ and $120 \mathrm{mV}$ decade ${ }^{-1}$ for $\beta_{\mathrm{a}}$ and $\beta_{\mathrm{c}}$, respectively, and Zhang and $\mathrm{Cheng}^{8}$ gave values of $60 \mathrm{mV}$ decade $^{-1}$ and $135 \mathrm{mV}$ decade ${ }^{-1}$. When the cathodic reaction was mainly controlled by mass transport-for example, for shorter immersion times- $i_{\text {corr }}$ was calculated using the simplified Stern and Geary equation:

$$
\mathbf{i}_{\text {corr }}=\frac{\beta_{\mathrm{a}}}{2.3 \mathrm{R}_{\mathrm{T}}}
$$

At $25^{\circ} \mathrm{C}$, the corrosion rate sharply decreased during the first hours of immersion. In addition, it was lowest for the highest rotation speeds. These results were expected since higher values of $\mathrm{R}_{\mathrm{T}}$ and lower anodic and cathodic current densities were observed when 

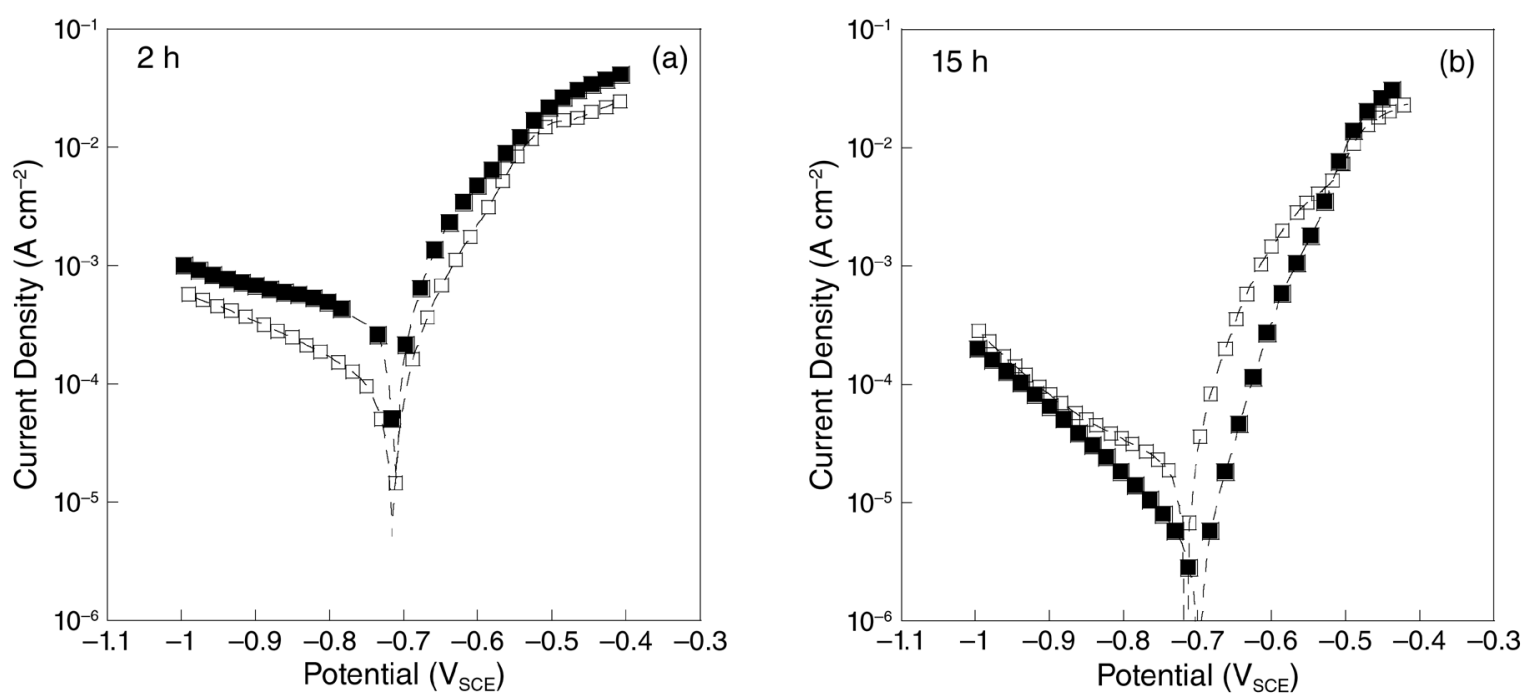

FIGURE 8. Current-voltage curves plotted at 1,000 rpm for different temperatures and after (a) $2 h$ and (b) $15 h$ of immersion in a $0.5 \mathrm{M} \mathrm{NaCl}$ solution saturated with $\mathrm{CO}_{2}:$ ( $\square$ ( $40^{\circ} \mathrm{C}$ and (口) $60^{\circ} \mathrm{C}$.
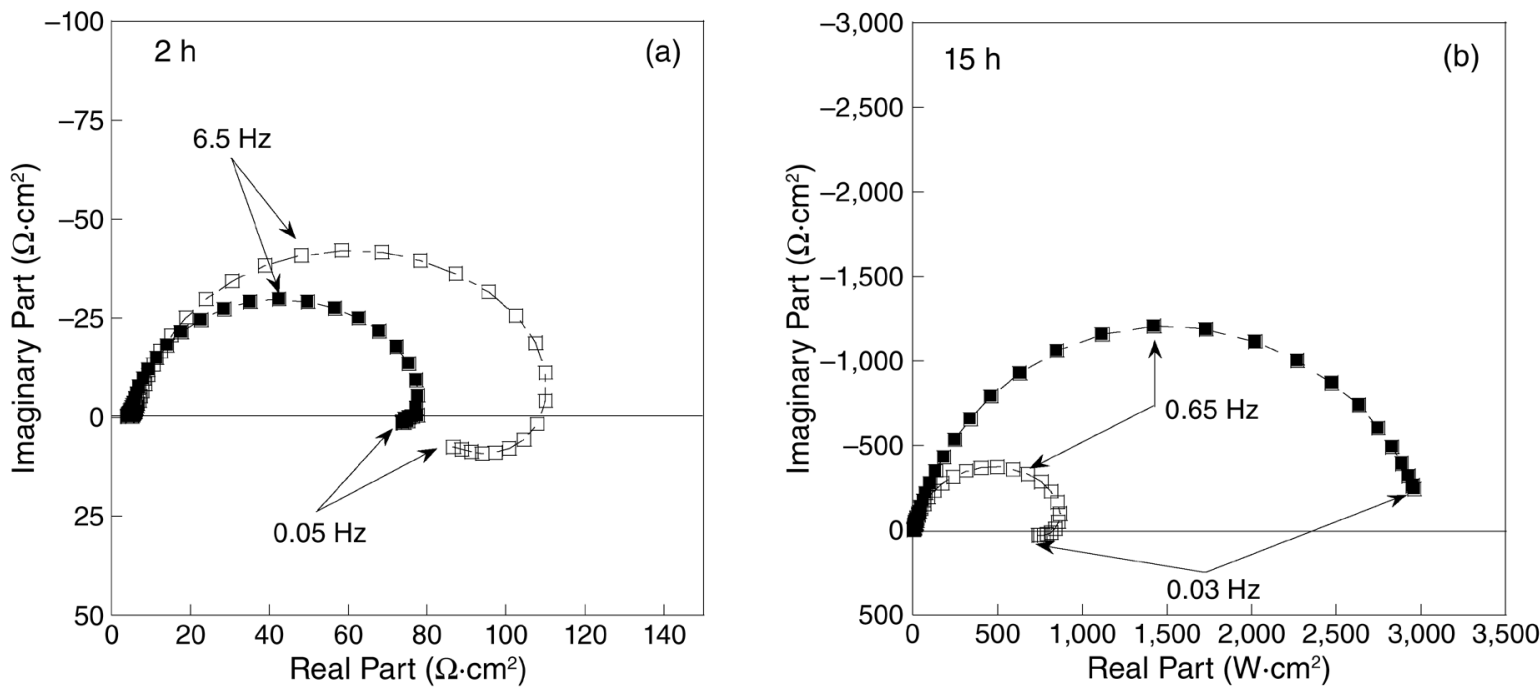

FIGURE 9. Electrochemical impedance diagrams plotted at the corrosion potential for different temperatures at $1,000 \mathrm{rpm}$ and after (a) $2 \mathrm{~h}$ and (b) $15 \mathrm{~h}$ of immersion in a $0.5 \mathrm{M} \mathrm{NaCl}$ solution saturated with $\mathrm{CO}_{2}:$ ( $\square$ ) $40^{\circ} \mathrm{C}$ and (口) $60^{\circ} \mathrm{C}$.

the immersion time and the electrode rotation rate increased. From the experimental data, the curves were graphically extrapolated to longer immersion times $(30 \mathrm{~h})$. It can be seen that the corrosion rate becomes low and poorly dependent on the two investigated parameters in agreement with impedance diagrams obtained consecutively for the three rotation speeds after $15 \mathrm{~h}$ of immersion (Figure 6[b]).

\section{Effect of Temperature}

The effect of the temperature was also investigated. This variable is among those which have the strongest influence on the corrosion resistance of the carbon steels in $\mathrm{CO}_{2}$ environments because it controls the deposition and the adhesion of the corrosion products mainly constituted of iron carbonate layers..$^{6-7,22}$
Electrochemical measurements were performed at $40^{\circ} \mathrm{C}$ and $60^{\circ} \mathrm{C}$ following the same experimental protocol as at $25^{\circ} \mathrm{C}$. Figures 8 and 9 show the polarization curves and the impedance diagrams obtained at $40^{\circ} \mathrm{C}$ and at $60^{\circ} \mathrm{C}$ after a preliminary hold time of $2 \mathrm{~h}$ and $15 \mathrm{~h}$ of immersion, respectively. In this case, the electrode rotation rate was fixed at $1,000 \mathrm{rpm}$. After $2 \mathrm{~h}$ of immersion, the polarization curves showed that both the anodic and cathodic current densities increased with temperature whereas for longer immersion times $(15 \mathrm{~h})$, an opposite behavior was observed. In addition, the cathodic branches of the polarization curves were modified by the increase of the temperature. This is in accordance with the size of the impedance diagrams and with the variation of the electrochemical parameters listed in Table 3. It can be seen that RT 
TABLE 3

Electrochemical Parameters Obtained from the Impedance Diagrams Presented in Figure 9

\begin{tabular}{lcccc}
\hline Immersion Time (h) & \multicolumn{2}{c}{$\mathbf{2}$} & \multicolumn{2}{c}{$\mathbf{1 5}$} \\
\hline Temperature $\left({ }^{\circ} \mathrm{C}\right)$ & 40 & 60 & 40 & 60 \\
$\mathrm{R}_{\mathrm{e}}\left(\Omega \cdot \mathrm{cm}^{2}\right)$ & 5.2 & 4.1 & 5.3 & 5.0 \\
$\mathrm{R}_{\mathrm{T}}\left(\Omega \cdot \mathrm{cm}^{2}\right)$ & 110 & 78 & 868 & 2959 \\
$\alpha$ & 0.79 & 0.79 & 0.85 & 0.81 \\
$\mathrm{Q}\left(\mathrm{M} \Omega^{-1} \mathrm{~cm}^{-2} \mathrm{~s}^{\alpha}\right)$ & 783 & 862 & 202 & 134 \\
$\mathrm{C}_{\text {eff }}^{1}\left(\mu \mathrm{Fcm}^{-2}\right)$ & 179 & 202 & 60 & 24 \\
\hline
\end{tabular}

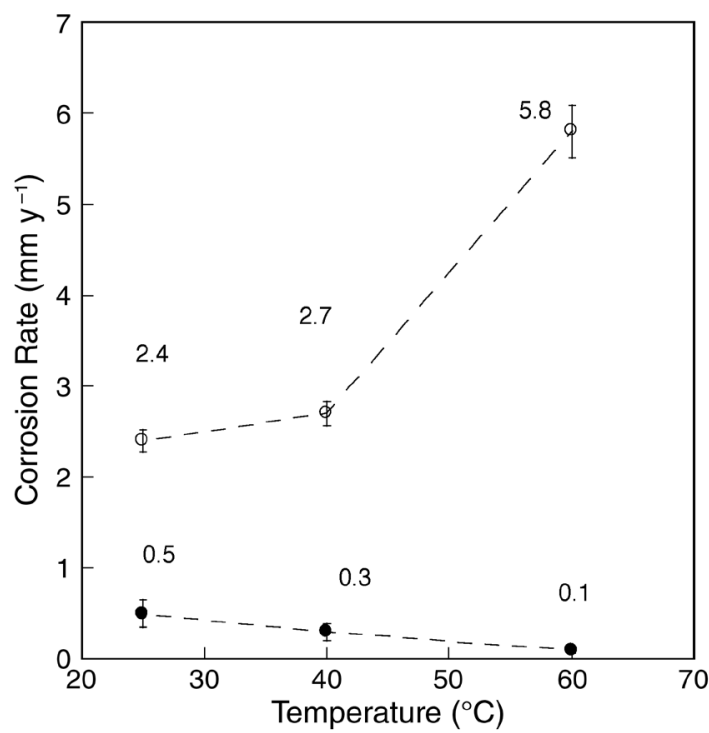

FIGURE 10. Corrosion rates of the carbon steel API $5 L-X 65$ calculated for 1,000 rpm, at different temperatures and two immersion times in $\mathrm{NaCl} 0.5 \mathrm{M}$ saturated with $\mathrm{CO}_{2}$ : (O) $2 \mathrm{~h}$ and $(0) 15 \mathrm{~h}$

increases and $\mathrm{C}_{\text {eff }}$ decreases only for longer immersion times, which is in agreement with works of Johnson and Tomson, ${ }^{23}$ who demonstrate that the precipitation kinetics of siderite $\left(\mathrm{FeCO}_{3}\right)$ is very slow, and high temperatures and long immersion times are required to precipitate it. These results confirm that the formation of the corrosion products on the steel surface is enhanced for higher temperatures, higher rotation speeds, and longer immersion times.

Corrosion rates calculated at $40^{\circ} \mathrm{C}$ and $60^{\circ} \mathrm{C}$ increase for a short immersion time $(2 \mathrm{~h})$, while an opposite behavior is observed after $15 \mathrm{~h}$ of immersion (Figure 10). Therefore, for $2 \mathrm{~h}$ of immersion, the iron dissolution was significant but the immersion time was not sufficient to allow a protective layer of iron carbonate to be formed. After $15 \mathrm{~h}$ of immersion, the solubility product of $\mathrm{FeCO}_{3}$ was exceeded and the iron carbonate blocked the steel surface.

\section{Scanning Electron Microscopy Characterization}

SEM observations were performed on the corroded steel surface after various exposure times for different rotation speeds and temperatures. Micrographs presented in Figures 11 and 12 reveal three main features:
-For the lower temperatures and immersion times, corrosion appeared heterogeneous, presenting a regular pattern similar to that found on the uncorroded samples, which corresponds to the two defined steel microconstituents $\alpha-\mathrm{Fe}$ and pearlite (Figure 1). It can be noted that the corrosion products preferentially deposits on the pearlitic zones, which act as cathodic sites with lower overpotentials favoring hydrogen evolution, as pointed out in the literature. ${ }^{13,24-25}$

-For the extreme experimental conditions (longer immersion times, higher temperatures, and greater rotation speeds), a relatively homogeneous layer of corrosion products covers the whole of the electrode surface, explaining the lower corrosion rates calculated from the electrochemical results.

-At the interface between two microconstituents of the steel (Figure 12), a stronger metal dissolution was observed indicating the formation of a galvanic coupling between pearlite and ferrite, resulting in selective dissolution of ferrite. These findings are in agreement with results previously found concerning galvanic coupling ( $\mathrm{Al} / \mathrm{Cu}$ or $\mathrm{Al} / \mathrm{Mg}$ couples) where a higher activity was shown at the interface between the anode and the cathode, as a result of the local current increase. ${ }^{26}$

\section{CONCLUSIONS}

* The corrosion behavior of API 5L-X65 carbon steel in a $\mathrm{CO}_{2}$ medium was investigated by electrochemical measurements and SEM observations. Electrochemical results showed that initially the corrosion process was controlled by mass transport, and then it was mainly controlled by activation when the immersion time, the rotation speed, and the temperature increased. From SEM observations, it was seen that at the beginning of immersion, corrosion products deposited preferentially on the pearlitic zones, which approximately constitutes $22 \%$ of the metal surface area. A galvanic coupling between pearlite and the ferritic matrix leads to the selective dissolution of ferrite. It was shown that when the immersion time, the flow, and the temperature increased, the corrosion products tend to cover the whole electrode surface explaining the decrease of the steel corrosion rate. Indeed, it was found that the active surface area decreased by at least a factor of three between $2 \mathrm{~h}$ and $15 \mathrm{~h}$ of immersion.

\section{ACKNOWLEDGMENTS}

This work was carried out within the international framework agreement between the Fondo Nacional de Ciencia, Tecnología e Innovación (FONACIT) in Venezuela and the Centre National de la Recherche Scientifique (CNRS) in France. M. Henriquez ex- 

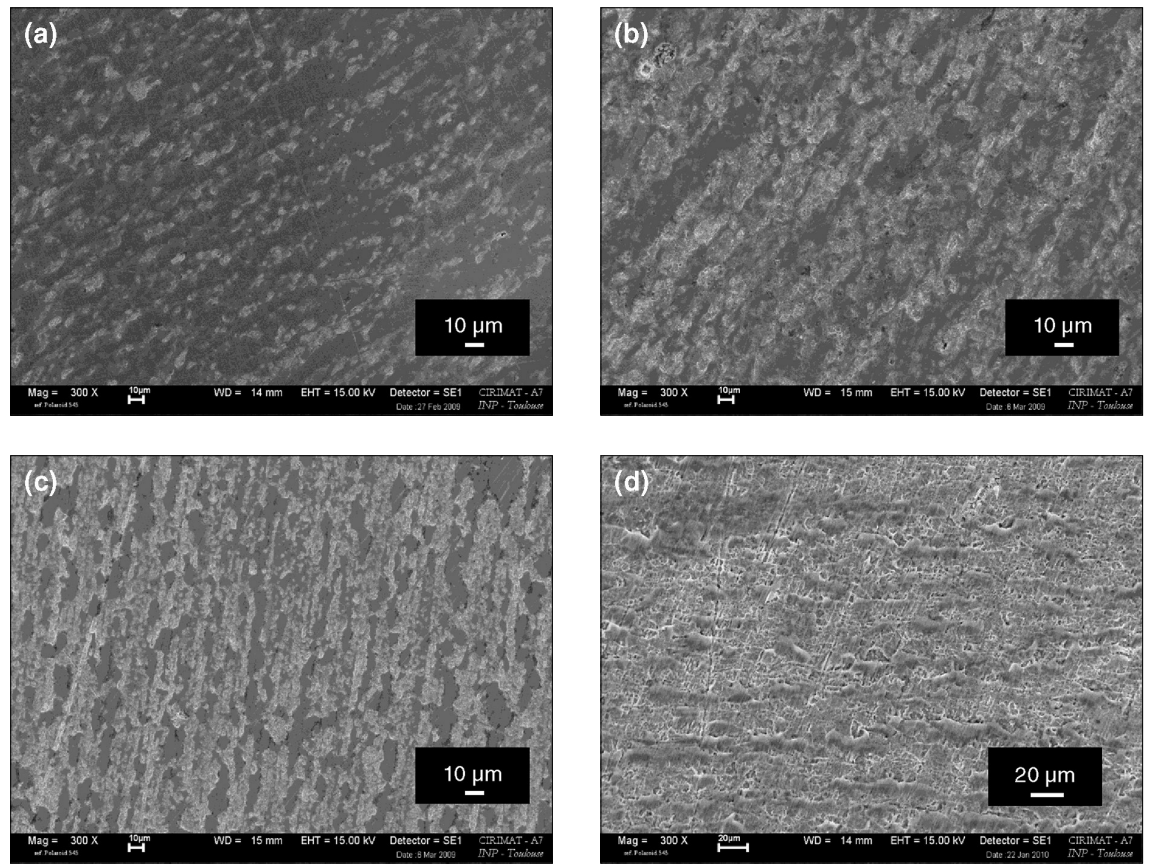

FIGURE 11. SEM observations of the corroded steel surfaces in a $0.5 \mathrm{M} \mathrm{NaCl}$ solution saturated with $\mathrm{CO}_{2}$ for different experimental conditions: (a) $400 \mathrm{rpm}$, (b) $1,600 \mathrm{rpm}$, (c) $25^{\circ} \mathrm{C}$, and (d) $60^{\circ} \mathrm{C}$.
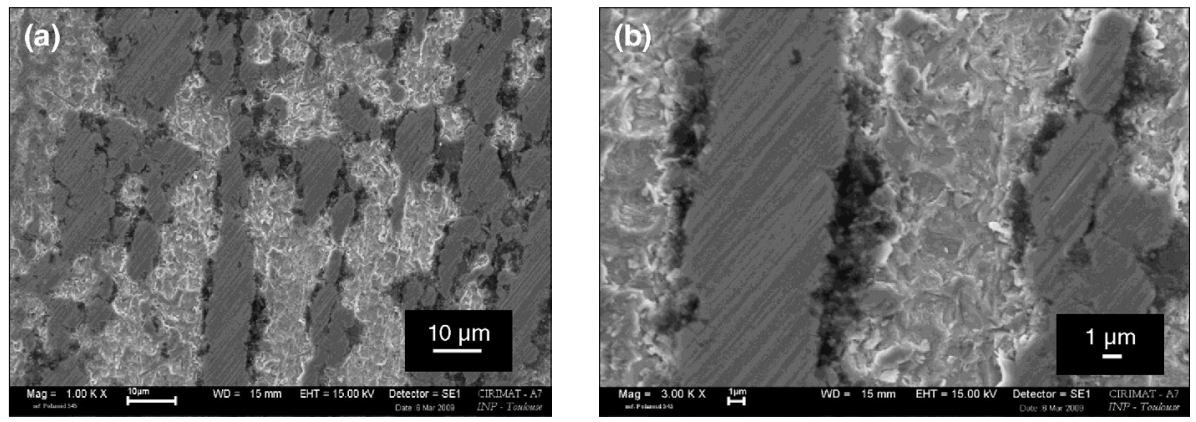

FIGURE 12. SEM observations of the corroded steel surfaces after $15 \mathrm{~h}$ of immersion in a $0.5 \mathrm{M} \mathrm{NaCl}$ solution saturated with $\mathrm{CO}_{2}$ at $1,000 \mathrm{rpm}$ and $25^{\circ} \mathrm{C}$.

presses her gratitude to PDVSA-INTEVEP for providing the scholarship for Ph.D. studies in France.

\section{REFERENCES}

1. J.L. Mora-Mendoza, S. Turgoose, Corros. Sci. 44 (2002): p. 1123

2. E. Eriksrud, T. Sontvedt, "Effect of Flow on $\mathrm{CO}_{2}$ Corrosion Rates in Real and Synthetic Formation Waters," CORROSION/1983, paper no. 83044 (Houston, TX: NACE International, 1983) 44.

3. G.I. Ogundele, W.E. White, Corrosion 42 (1986): p. 71.

4. R. Quiroz, A. Rosales, E. Baron, Rev. Latinoam. Metal. Mater. 29 (2009): p. 84.

5. A. Dugstad, Corrosion 92 (1992): p. 14.

6. K. Videm, A. Dugstad, Mater. Perform. 28, 3 (1989): p. 63.

7. K. Videm, A. Dugstad, Mater. Perform. 28, 4 (1989): p. 46

8. G.A. Zhang, Y.F. Cheng, Corros. Sci. 51 (2009): p. 1589.

9. B. Linter, G. Burstein, Corros. Sci. 41 (1999): p. 117.

10. E. Remita, B. Tribollet, E. Sutter, V. Vivier, F. Ropital, J. Kittel, Corros. Sci. 50 (2008): p. 1433.

11. D. You, N. Pebere, F. Dabosi, Corros. Sci. 34 (1993): p. 5.

12. D.S. Carvalho, C.J.B. Joia, O.R. Mattos, Corros. Sci. 47 (2005): p. 2974.

13. F. Farelas, M. Galicia, B. Brown, S. Nešić, H. Castaneda, Corros. Sci. 52 (2010): p. 509.
14. P. Li, T.C. Tan, J.Y. Lee, Corros. Sci. 38 (1996): p. 1935.

15. G. Zhang, C. Chen, M. Lu, C. Chai, Y. Wu, Mater. Chem. Phys. 105 (2007): p. 331.

16. M. Keddam, O.R. Mattos, H. Takenouti, J. Electrochem. Soc. 128 (1981): p. 257.

17. G.J. Brug, A.L.G. Van Den Eeden, M. Sluyters-Rehbach, J.H. Sluyters, Electroanal. Chem. 176 (1984): p. 275.

18. M.E. Orazem, N. Pebere, B. Tribollet, J. Electrochem. Soc. 153 (2006): p. B129.

19. B. Hirschorn, M.E. Orazem, B. Tribollet, V. Vivier, I. Frateur, M. Musiani, Electrochim. Acta 55 (2010): p. 6218.

20. ASTM G102-89(2010), "Standard Practice for Calculation of Corrosion Rates and Related Information from Electrochemical Measurements" (West Conshohocken, PA: ASTM International, 2010).

21. M. Stern, L. Geary, J. Electrochem. Soc. 104 (1957): p. 56.

22. P. Benezeth, J.L. Dandurand, J.C. Harrichoury, Chem. Geol. (2009): p. 265.

23. M.L. Johnson, M.B. Tomson, Corrosion 91 (1983): p. 268.

24. L.D. Paolinelli, T. Perez, S.N. Simison, Corros. Sci. 50 (2008): p. 2456.

25. J.-L. Crolet, N. Thevenot, S. Nešić, Corrosion 54 (1998): p. 194.

26. J.-B. Jorcin, C. Blanc, N. Pebere, B. Tribollet, V. Vivier, J. Electrochem. Soc. C46 (2008): p. 155. 